\title{
Egg parameters of the Red Wattled Lapwing (Vanellus indicus) in agricultural ecosystem of Punjab
}

\author{
Manpreet Kaur* and K. S. Khera \\ Department of Zoology, Punjab Agricultural University, Ludhiana (Punjab), INDIA \\ *Corresponding author's email: binner_manpreet@yahoo.com \\ Received: September 10, 2016; Revised received: April 6, 2017; Accepted: July 11, 2017
}

\begin{abstract}
The Red Wattled Lapwing is an important bird of the agro-ecosystem of the Punjab state, feeding on insects, seeds and nectar. The present study was carried out to gather information on the egg parameters (morphometry and its components), which is lacking for this species. The eggs were observed in the nest constructed in the agricultural fields of Punjab Agricultural University (PAU), Ludhiana, Punjab. Egg length, width and weight were measured using vernier caliper and portable weighing balance, respectively, in laboratory. The egg parameters like egg volume, specific gravity and shape index were also calculated. Weight of egg components (yolk, albumen and shell) were also measured using weighing balance. Results revealed that average values of egg breadth, length and shape index were: $30.05 \pm 0.331(\mathrm{~mm}), 41.29 \pm 0.573(\mathrm{~mm})$ and $72.83 \pm 0.930$, respectively. Whereas whole egg weight, albumen weight, yolk weight, shell weight, albumen percentage, yolk percentage, shell percentage, egg volume and specific gravity were $17.49 \pm 0.634(\mathrm{gm}), 7.17 \pm 0.374(\mathrm{gm}), 9.05 \pm 0.233(\mathrm{gm}), 1.26 \pm 0.070(\mathrm{gm}), 40.84 \pm 0.941$ $(\%), 51.92 \pm 0.830(\%), 7.22 \pm 0.280(\%), 17.07 \pm 0.531\left(\mathrm{~cm}^{3}\right)$ and $1.02 \pm 0.009\left(\mathrm{gm} / \mathrm{cm}^{3}\right)$, respectively. This study provides important information that can help the avian taxonomists in species classification, as bird's egg diverges widely in shape, volume, weight and percentage of albumen, yolk and shell. Therefore, we can use the egg parameters as additional information in bird systematic.
\end{abstract}

Keywords: Egg Component, Egg Parameters, Red Wattled Lapwing, Specific gravity, Shape index

\section{INTRODUCTION}

The Red Wattled Lapwing (Vanellus indicus) is a common and widespread wading bird of the Indian Subcontinent (Sethi et al., 2011). The most distinguishable character of this bird is the fleshy red wattle in front of the eye and the red ring around the eye. Sexes are alike (Madhava and Botejue, 2009). It has characteristic loud alarm calls which are variously rendered as did he do it or pity to do it leading to colloquial names like the did-he-do-it bird. Usually seen in pairs or small groups not far from water but may form large flocks in the non-breeding season (winter) (Gupta et al., 2011).

The bird's egg is one of most complex and highly differentiated reproductive germinal cell accumulates relatively enormous amounts of food substances (yolk and albumen material). Bird's egg diverges widely in shape, volume, weight and the amount of yolk, albumen and shell. The shape of the egg is recognizable species characteristic. Species within a genus lay egg diverge widely from oval to conical shape, with one end rounded and the other more pointed (Al-Obaidi and Al-Shadeedi, 2012).

Morphometrics in general refers to measurements of the body parts (Kabir et al., 2012). Egg morphometric parameters such as egg length, breadth, weight and shape index are relevant to a number of studies, such as population and ecological morphology (Narushin, 2005), predicting chick weight (Narushin et al., 2002), egg hatchability (Narushin and Romanov, 2002a,b), avian biology, taxonomy, classification and genetics. Internal egg quality parameters such as albumen weight and yolk weight are very important from nutritional and cholesterol content for human consumption (Sparks, 2006). Both internal and external egg parameters are affected by genotype. Genetic differences in eggshell quality characteristics exist between species, and between breeds, strains and families within the lines. Genotype has direct influence on egg weight and eggshell characteristics (Hrncar et al,. 2014).

Studies on varied aspects on avian ecology in recent past have been extensively carried out by Gupta and Bajaj, 2000, Gupta and Kumar, 2009, Gupta et al., 2010. However, no such information is available on egg parameters of Red Wattled Lapwing (Vanellus indicus). So, in view of the above details present study was planned to provide first hand data on egg parameters of Red Wattled Lapwing (Vanellus indicus) in agricultural ecosystem of Punjab.

\section{MATERIALS AND METHODS}

Nine Red Wattled Lapwing (Vanellus indicus) freshly laid eggs were collected from different nests ( 9 nests) 
Table 1. Egg Parameters of Red Wattled Lapwing.

\begin{tabular}{llll}
\hline Parameters $(\mathbf{n}=9)$ & Maximum & Minimum & Mean \pm SE \\
\hline Egg breadth $(\mathrm{mm})$ & 31.36 & 28.68 & $30.05 \pm 0.331$ \\
Egg length $(\mathrm{mm})$ & 44.1 & 38.61 & $41.29 \pm 0.573$ \\
Egg shape index & 75.8 & 67.18 & $72.83 \pm 0.930$ \\
Egg weight (gm) & 19.94 & 15.54 & $17.49 \pm 0.634$ \\
Egg albumin weight $(\mathrm{gm})$ & 9.19 & 5.6 & $7.17 \pm 0.374$ \\
Egg yolk weight $(\mathrm{gm})$ & 10.2 & 8 & $9.05 \pm 0.233$ \\
Egg shell weight $(\mathrm{gm})$ & 1.55 & 0.93 & $1.26 \pm 0.070$ \\
Egg albumin $(\%)$ & 46.49 & 36.02 & $40.84 \pm 0.941$ \\
Egg yolk $(\%)$ & 56.6 & 46.54 & $51.92 \pm 0.830$ \\
Egg shell $(\%)$ & 8.37 & 5.27 & $7.22 \pm 0.280$ \\
Egg volume $\left(\mathrm{cm}^{3}\right)$ & 19.19 & 15.11 & $17.07 \pm 0.531$ \\
Egg specific gravity $\left(\mathrm{gm} / \mathrm{cm}^{3}\right)$ & 1.06 & 0.96 & $1.02 \pm 0.009$ \\
\hline
\end{tabular}

without developed embryo from agricultural fields of Punjab Agricultural University, Ludhiana, Punjab from $8^{\text {th }}$ April to May $3^{\text {rd }}$ of 2013 and brought to laboratory and stored in refrigerator at $4^{\circ} \mathrm{C}$ until analysis. Egg length $(\mathrm{mm})$ and width $(\mathrm{mm})$ were measured using digital vernier caliper while egg weight $(\mathrm{g})$ was measured using a portable digital weighing balance. Egg volume was estimated from length (L) and breadth (B), data were calculated using an empirical formula $\left((0.457) \times(\mathrm{L}) \times\left(\mathrm{B}^{2}\right) \times 10-{ }^{3} \mathrm{ml}\right)$ calibrated to Northern Lapwing eggs by Galbraith, (1988). Specific gravity (Egg weight $(\mathrm{g}) /$ Egg volume $\left.\left(\mathrm{cm}^{3}\right)\right)$ and shape index ([egg width/egg length] $\times 100$ ) were determined according to Stadelman and Cotterill, (1995). Weights of the egg shell, yolk and albumen materials were determined using an electronic weight balance after cracking the shell and separating the yolk from albumen materials. Percentages of egg components (shell, yolk and albumen materials) as a ratio to total egg weight were determined by using the equation (Egg weight (gm)/Egg weight $(\mathrm{gm}) \times 100)($ Stadelman and Cotterill, 1995) . The values were expressed as mean \pm standard error.

\section{RESULTS AND DISCUSSION}

Egg parameters have not been reported to our knowledge for any lapwing species in the wild. The mean values of the egg length, egg breadth, egg shape index, egg weight, egg volume, egg specific gravity, egg shell weight, egg yolk weight, egg albumen weight, egg shell \%, egg yolk \% and egg albumen $\%$ of Red Wattled Lapwing eggs are shown in Table 1.

In general eggs of birds have oval shape with little distinction among species. Despite of little distinction the shape of eggs has been considered as an essential element to portray species of birds. In this study the eggs of Red Wattled Lapwing demonstrated comparable ovalish shape with one end rounded and the other pointed, subsequently they were practically indistinctive with eye the extent that shape was concerned exclusively without regard to size and shading. The shape of egg can be expressed numerically by the shape index. The shape indices of Red Wattled Lapwing eggs demonstrated the range from 67.18 to 75.8 which was lower than Pheasant, Chukar, Quail, Guinea fowl egg (79.63, 77.30, 78.93, 79.57, respectively) (Song et al,. 2000).

Weights of egg albumen (7.17 g) and yolk (9.05 g) were significantly higher in the present study as compared to egg albumen $(3.70 \mathrm{~g})$ and yolk $(5.00 \mathrm{~g})$ weights recorded by Kabir et al. (2012) in Quail. But egg shell weight recorded by Kabir et al,. 2012 in Quail was higher as compared to Red Wattled Lapwing eggs (1.26 g).

The proportions of yolk, white and shell in the eggs of birds vary greatly between species (Romanoff and Romanoff, 1949). The eggs of species with precocial development, particularly waterfowl, have large yolks (about 35\% egg weight) compared to the eggs of birds with altricial development (about 20\% egg weight) (Al -Obaidi and Al-Shadeedi 2012). According to this study, Red Wattled Lapwing had the largest proportion of yolk $(51.92 \%)$, which is relatively higher than Pheasant, Chukar, Quail, Guinea fowl egg (35.7\%, $33.9 \%, 31.4 \%$, 30.6\%, respectively). Proportions of albumen to the total egg weight were higher in Pheasant, Chukar, Quail, Guinea fowl egg (55.6\%, 57.4\%, $61.2 \%, 55.9 \%$, respectively) (Song et $a l, .2000$ ) as compared to Red Wattled Lapwing (40.84\%).

Egg volumes of Dove and Quail recorded by Kabire et $a l,$. (2012) as 9.05 \pm 0.84 and $9.59 \pm 0.81 \mathrm{~cm} 3$ respectively, were found lower as compared to Red Wattled Lapwing eggs $\left(17.07 \mathrm{~cm}^{3}\right)$. Specific gravity of an egg indicates the quantity of shell relative to other components of the egg. Differences in specific gravity among eggs of similar weights are mainly due to variations in the amount of shell (Butcher and Miles, 1991). According to Rayan et al,. (2010), specific gravity of layer breeder hens at different ages $(25,47$ and 61 weeks) is $1.070,1.070$ and $1.067 \mathrm{gm} / \mathrm{cm}^{3}$ respectively. The present results lend support to the findings of Rayen et al, (2010).

\section{Conclusion}

Generally, it can be concluded that Red Wattled Lapwing eggs had large proportion yolk content, its chicks show precocial development. It was also observed that 
external and internal egg parameters of Red Wattled Lapwing are significantly different from other bird species. The present report provides important information that can help the avian taxonomists in species classification.

\section{ACKNOWLEDGEMENTS}

I am very thankful to Dr. G.K. Sangha, Head of the Department of Zoology, Punjab Agricultural University , Ludhiana that provided me every need regarding this research work.

\section{REFERENCES}

Al-Obaidi, F.A. and Al-Shadeedi, S.M. (2012) Egg structural characteristics of Pygmy Cormorant (Microcarbo pygmaeus). Res. Opin. Anim. Vet. Sci. 2(1) : 4-6.

Butcher, G. D. and Miles, R. D. (1991) Egg Specific Gravity -Designing a Monitoring Program. www.edis.ifas.ufl.edu.

Galbraith, H. (1988) Effects of egg size and composition on the size, quality and survival of Lapwing (Vanellus vanellus) chicks. J. Zool.214: 383-98.

Gupta, R.C. and Bajaj, M. (2000) Preliminary observation on a rare lapwing species, white tailed (Vanellus leucurus). J. Natcon 12 (2): 197-203.

Gupta, R.C. and Kumar, S. (2009) Determination of avian biodiversity in Morni hills in district Panchkula, Haryana. J. Adv. Zool.30(1): 44-53.

Gupta, R.C., Parasher, M. and Kausik, T.K. (2010) Analysis of avifauna of Chilchilla Bird Sanctuary in Haryana, India.J. Adv. Zool. 30(1): 35-44.

Gupta, R.C., Kausik, T.K. and Parasher, M. (2011) On the death of an enchanting bird sanctuary and robust wetland in Kurukshetra district in Haryana, India. Internat. J.Current LifeSci. 1(3):48-54.

Hrncar, C., Hanusova, E., Hanus, A. and Bujko, J. (2014) Effect of genotype on egg quality characteristics of Japanese quail (Coturnix Japonica) J. Anim. Sci., 47(1): 6-11.

Kabir, M.A., Islam, M.S. and Dutta, R.K. (2012) Egg mor- phometric analyses in chickens and some selected birds. J. zool. Rajshahi Univ. 31: 85-87.

Madhava, W. and Botejue, S. (2009) An observation of Vanellus indicus boddaert, 1783 (Aves: Charadriidae) feed on an exotic Laevicaulis altae ferussae, 1821 (Gastropoda: Veronicellidae) at a human habitation in Sri lanka. Taprobanica, 1(1): 36-38.

Narushin, V.G. and Romanov, M.N.(2002a) Physical characteristics of chicken eggs in relation to their hatchability and chick weight. Paper \# 026066 in CD-ROM Proceedings of ASAE Annual International Meeting/ CIGRWorld Congress, Chicago, IL.

Narushin, V.G. and Romanov, M.N. (2002b) Egg physical characteristics and hatchability. Worlds Poult. Sci. 58:297-303.

Narushin, V.G., Romanov, M.N. and Bogatyr, V.P. (2002)) Relationship between pre-incubation egg parameters and chick weight after hatching in layer breeds. Biosystems Eng. 83:373-381.

Narushin, V.G. (2005) Egg geometry calculation using the measurements of length and breadth. Poult. Sci. 84: 482 -484 .

Rayan, G. N., Galal, A., Fathi, M. M. and Attar, A. H. (2010) Impact of layer breeder flock age and strain on mechanical and ultrastructural properties of egg shell in chicken. Int J Poult Sci. 9 (2): 139-147.

Romanoff, A.L. and Romanoff, A. (1949) The Avian Egg. John Wiley and Sons Co., New York.

Sethi, V.K., Bhatt, D., Kumar, A. and Naithani, A.B. (2011) The hatching success of ground- and roof-nesting Redwattled Lapwing Vanellus indicus in Haridwar, India. Forktail 27: 7-10.

Song, K. T., S. H. Choi, and Oh, H. R. (2000) A comparison of egg quality of pheasant, chukar, quail and guinea fowl. Asianaustralas. J. Anim. Sci. 7: 986-990.

Sparks, N.H. (2006) The hen's egg: Is its role in human nutrition changing? World's Poult. Sci. J. 62: 308-315.

Stadelman, W.J. and Cotterill, O.J. (1995) Egg science and Technology. An Imprint of the Haworth Press Inc, New York, London, pp 1-590. 